https://doi.org/10.5817/OS2020-2-6

\title{
Linguistics as a Crossroad Between Law, Politics, and Conflict
}

HENZELMANN, M. (ed.): Linguistik als diskursive Schnittstelle zwischen Recht, Politik und Konflikt. Hamburg: Verlag Dr. Kovač, 2018. 315 S. Studien zur Slavistik, Band 42. ISBN 978-3-8300-9459-3.

This collection is dedicated to the role of language as an instrument of expression in the sphere of law (in its various aspects) and politics, including political journalism, also at places touching history, religion, the problems of minorities and their integration in society. It is made up of 17 articles, written in German, English and Russian, dealing with the legal discourse, political language, problems in translating and interpreting, and linguistics and conflict. The articles were presented at an international scholarly conference held in February 2017 at the Institute of Slavic Studies at Dresden University of Technology. The conference was organized by Martin Henzelmann, and the goal was to focus on new linguistic challenges in law, history, politics, comparative studies, translation, interpretation, and managing of conflicts. An alumnus of the same university is the above-mentioned editor of the collection, Martin Henzelmann, a PhD holder in Slavonic philology and a Master in Romance studies, who currently works as a research assistant at the Institute of Slavic Studies at the University of Hamburg. The collection is addressed to linguists-especially Slavists and researchers of the history of language, legal language in Slavic speaking countries and interpreting. The authors of the articles highlight current trends and problems in diverse areas: the recent conflict in Ukraine, legal terminology in Slovenia, Poland, Russia, and in the EU, the history of the Macedonian Standard Language, Turkish as a Minority Language in Bulgarian education, etc.

After the editorial, in which the book's editor gives a short presentation of its conception, five thematic sections come, serving to group together the rest of the articles included in the collection: 1. Legal Discourse and Legal Language at Past and at Present; 2. Historical Aspects of Linguistics as a Mirror of Political and Social Tendencies; 3. Linguistics between Political Routine and Language Acquisition; 4. Problems in Translation and Interpreting; 5. Linguistic Conceptualization of Conflicts.

The first of the sections mentioned starts with a paper by Alenka Kocbek from Koper, Slovenia, entitled "The Power of Legal Language-Legal Language as an Instrument of Power" (pp. 15-33) and is dedicated to the essence and the main features of legal 
language. The explanations the author provides are supported by a rich and engaging illustrative material garnered from different epochs (from the Middle Ages to the present) and geographical areas (from Slovenia to the USA). We admit that we were pleasantly surprised by the variety of the topic, which contrasts with the generally accepted notion that law is a dry matter. Because, as the author of the article says herself, law is a profession of words. Among the aspects covered by the article are the effects that legal language produces, universal features of legal languages, the need for researching them in a diachronic perspective. Further, specific attention is paid to legal Slovene, created through translation-Alenka Kocbek's native tongue, and to legal German, legal Italian, legal English. Since in Slavic studies juridical languages have only slightly been researched in a historical and comparative aspect, the present article could be a good starting point for such a future endeavor.

Liana Goletiani (Milan, Italy) with her piece of research ("Правовая культура России в эпоху великих реформ: к изучению правового метадискурса С. И. Зарудного") follows (pp. 35-54), highlighting Russian legal culture and language. In it, she reviews the multifarious activity of Sergey Zarudni-the "father" of the legal reform in Russia, who lived in the first half of the 19 th $\mathrm{c}$. and was a translator in the sphere of trade law from juridical Italian into Russian.

In the third article (“"Писмьо студенту': Лев Толстой и дискурс права”), written by Holger Kuße (Dresden, Germany, pp. 55-68), we are acquainted with the discrepancy of ideas between the views of Leo Tolstoy on negating law and those of Leon Petrażycki regarding the same. While according to Petrażycki morality springs from law, to the great Russian writer and philosopher Tolstoy law is just a means of oppression that the rulers exercise over the ruled ones. The object of attention in this dispute hasn't yet ceased to be current.

From Slovenia and Russia the attention is next directed at Poland in Martin Henzelmann's (Hamburg, Germany) research: "Nature Conservation in Poland between Ecological and Legal Discourse: A Linguistic Interface in Practice" (pp. 69-84). Here, the history of environment protection in Poland is traced, and it dates from as early as the 19 th $\mathrm{c}$. The Polish Act on the Protection of Nature is investigated as well as other legal acts and the terminology used in them. Unresolved issues are delineated.

The articles from the second section are dedicated to linguistic themes in a historical aspect. András Zoltán (Budapest, Hungary) discusses "Ruthenian-Russian Language Contact in the 15th Century" (pp. 87-102), and analyses the influence of Ruthenian chancellery language in Lithuania in the $15^{\text {th }} \mathrm{c}$. on the Russian language.

Robert Dittmann (Prague, Czech Republic) highlights "Slavic Tongues in the Eucharistic Liturgy in the Bohemian Lands until 1621" (pp. 103-140), and traces the use of the Old Slavic language in liturgies in Czech lands in the period between the time of Cyril and Methodius and the Hussite reformation. 
The paper "The Kitaby as Evidence for Language Assimilationist Tendencies between the Tatars in the Polish-Lithuanian Commonwealth in the 17th Century" (pp. 141-153) by Ruben Biewald (Giessen, Germany) tackles the extremely interesting matter of using the Arabic alphabet in Polish-Belarusian texts in the so-called Tatar kitabs of the $17^{\text {th }} \mathrm{c}$., which involves religion, too, in the present valuable collection of articles.

Alexander Böhnisch (Göttingen, Germany) gives "A Short Overview of the Cultural and Linguistic Contact between Russians and Uralians" (pp. 155-165). He researches the first linguistic contacts between the Eastern Slavonic tribes, ancestors of the present-day Russians, and the Uralic peoples.

Helmut Wilhelm Schaller (Munich, Germany) focuses on "The Macedonian Language: A South Slavonic Language between Science and Politics" (pp. 167-176). He enters the sphere of politics and shows that Bulgarian scholars have the full right to claim that Macedonian is closely related to Bulgarian.

In the comparatively short third section Ekaterina Zacharčuk (Khmelnytsky, Ukraine) analyses values with different nationalities and therefore, she continues with the political slant by presenting the results of an experiment concerning the inquiry among Afghan refugees in Austria ('Ценностные концепты 'я-новый' и 'я-чужой' в текстах неинституционального политического дискурса (на примере текстов молодых людей с разным правовым статусом: беженцев и не беженцев", pp. 179-190). The experiment shows the picture of the world as seen through the eyes of refugees.

Milena Jordanova (Sofia, Bulgaria) investigates "The Role of the Turkish Language as a Foreign Language at Universities in Bulgaria” (pp. 191-197), a delicate issue and one that until recently was almost forbidden to discuss in Bulgaria. The paper discusses the history of Turkish language education in Bulgaria and focuses on current practices in Turkish language teaching at Universities. It considers the reasons for the necessity of language training and qualified specialists in Turkish or Turkic Studies in the country.

The two articles included in the fourth section have to do with problems of translation. Radegundis Stolze (Darmstadt, Germany) shows "Culture-specific Phenomenology in Political and Legal Translation" (pp. 201-217) and presents what is necessary to be a good translator. And Mihai Draganovici (Bucharest, Romania) reflects "Challenges of Language Transfer in Interpreting in the Example of the Nuremberg Trials" (pp. 219-235). Once more he turns our attention to both law and politics, combined with the mastery of good translation.

The final, fifth section combines politics with its continuation by other means-that is, with war. In the first article by Marina Želtuchina \& Anatolij Omel'čenko (Volgograd, Russia) with the title "Enemy Image Verbalization in Russian Discursive Media Space 
as Reflection of the Conflict of Interests in Different Spheres of Human Activity" (pp. 239-262), the problem of the verbal description of the enemy in the eyes of Russian journalists is discussed.

Marina Scharlaj (Dresden, Germany) examines similar themes ("“Пятая колонна'. Идеологическая агрессия в современном политическом дискурсе России", pp. 263-276). She reviews the different forms of speech aggression in Russian media. It is once again about an enemy, but this time one who secretly and furtively acts inside Russia in the interests of the West, undermining Russian values. "The fifth column"-those are the traitors, provocateurs and spies. It is one more a matter of aliens in society, but this time they are not refugees, just compatriots thinking differently from the rest.

Vladimir Karasik's (Volgograd, Russia) paper "Clouding of Speech Meaning as a Communicative Practice" (pp. 277-289) follows. Using the initial line in its abstract, we can generalize that "the article deals with clouding of speech meaning, which is treated as deliberately making the message obscure for an addressee, so as to exercise dominance over them and/or exclude outsiders from communication". Then from Russia we go on to Ukraine via Marianna Novosolova (Dresden, Germany) and Ekaterina Jacura's (Donetsk, Ukraine) article ("Обсуждение терминологии конфликта как признак открытости украинского общества"), discussing the armed conflict in Eastern Ukraine and analyzing the reactions to it in Ukrainian society (pp. 291-307). In it, the relations in a closed totalitarian society (the contemporary Russian society is meant) and the open democratic society (that the one in Ukraine should be) are discussed regarding the military conflict in Donbas.

At the end, there is some concise information about the authors, their university career, their areas of research, and occupations (pp. 311-315). In spite of its comparatively narrow thematic orientation, the collection is exceptionally many-sided and varied. Different problems of juridical and political linguistics in different historical periods, in different parts of Europe are illuminated. The articles presented in this volume focus on new insides, interesting details and results, and they are worth reading quality papers. Therefore, the volume helps us to understand the interaction between law, politics, and conflict in a diachronic and a synchronic perspective. The goal the editor has set himself by publishing it has been fulfilled more than successfully.

Margarita Georgieva, Ivan G. Iliev 


\section{References:}

HENZELMANN, M. (ed.): Linguistik als diskursive Schnittstelle zwischen Recht, Politik und Konflikt. Hamburg: Verlag Dr. Kovač, 2018. 315 S. Studien zur Slavistik, Band 42. ISBN 978-3-8300-9459-3.

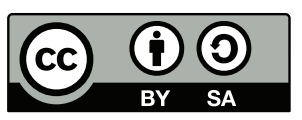

This work can be used in accordance with the Creative Commons BY-SA 4.0 International license terms and conditions (<https://creativecommons.org/licenses/by-sa/4.0/legalcode>). This does not apply to works or elements (such as images or photographs) that are used in the work under a contractual license or exception or limitation to relevant rights.

https://doi.org/10.5817/OS2020-2-7

\section{Словарь par excellence - исторически первый в контексте словацкой русистики}

GRIGORJANOVÁ, T. - GAJARSKÝ, L.: Slovník rusko-slovenských medzijazykových homoným. Brno: Tribun EU, 2019. 127 s. ISBN 978-80-263-1544-5.

Проблема межъязыковой омонимии, как одной из наиболее сложных задач языкового исследования, возникает в тесной связи с глобализацией общения. Активизация интерференции лексических и семантических заимствований является наглядным примером воздействия этого процесса, который затрагивает все сферы жизни, включая язык.

Сравнительное изучение межъязыковой омонимии связано с другими важными теоретическими проблемами лингвистики, включая широко распространённый билингвизм, полилингвализм и языковые контакты на синхронной основе.

В настоящее время в лингвистике проблема межъязыковых омонимов (точно так же в прошлом слова разных языков, которые имели одинаковую внешнюю форму, но разные значения, привлекали внимание лингвистов) адекватно решается и изучается не только на генетически родственных языках ${ }^{1}$. Можно

1 См., напр.: LOTKO, E.: Zrádná slova v polštině a češtině. Olomouc: Filozofická fakulta Univerzity Palackého, 1987; BARTÁKOVÁ, J.: K zradnostiam v blizkopríbuzných jazykoch. In: ŠLOSAR, D. (red.): Sborník prací Filozofické fakulty brněnské univerzity. Brno: Masarykova univerzita, 1998, s. 151-159; HORÁKOVÁ, R.: Medzijazyková homonymia pri geneticky príbuzných jazykoch. Filologická revue, roč. 2, 1999, č. 4, s. 52-56; HORÁKOVÁ, R.: Slovinsko-slovenská homonymia z konfrontačného hladiska. In: PANČÍKOVÁ, M. (ed.): Philologica LIII. Zborník Filozofickej fakulty Univerzity Komenského v Bratislave, 2001, s. 175-180; HORÁKOVÁ, R.: Interlingválne homonymá ako lexikografický problém. 